\title{
Purification and Characterization of a Thermostable $\beta$-Xylosidase from Thermomonospora fusca
}

\author{
By SUSAN L. BACHMANN AND ALAN J. MCCARTHY* \\ Department of Genetics and Microbiology, Life Sciences Building, University of Liverpool, \\ PO Box 147, Liverpool L69 3BX, UK
}

(Received 4 August 1988; revised 10 October 1988; accepted 27 October 1988)

\begin{abstract}
Xylan-degrading enzymes, including $\beta$-xylosidase (EC 3.2.1.37), were induced when Thermomonospora fusca was grown at $50{ }^{\circ} \mathrm{C}$ in liquid medium containing $0.2 \%$ xylan. The intracellular $\beta$-xylosidase activity was concentrated and characterized by fast protein liquid chromatography and gel electrophoresis. A zymogram technique was developed to identify $\beta$ xylosidase directly on polyacrylamide gels. A single enzyme (168 kDa; pI 4.37) was identified and purified to homogeneity. The consistent detection of a single band on denaturing SDS gels suggested that the enzyme was composed of identical subunits; since the subunit molecular mass was $56 \mathrm{kDa}$, a trimeric structure is suggested. High activity against $p$-nitrophenyl $\beta$-Dxylopyranoside (pNPX) occurred in the pH range 5.0-9.0 and temperature range $40-60{ }^{\circ} \mathrm{C}$. The enzyme was stable at room temperature at $\mathrm{pH} 6 \cdot 0-8.0$; it had a half-life of $8 \mathrm{~h}$ at $65^{\circ} \mathrm{C}$, and of $1.5 \mathrm{~h}$ at $70^{\circ} \mathrm{C}$. The purified enzyme did not exhibit any detectable activity against arabinoxylan, carboxymethylcellulose or $p$-nitrophenyl $\beta$-D-glucopyranoside. The enzyme had a $K_{\mathrm{m}}$ of $0.89 \mathrm{~mm}$ (pNPX) and was inhibited by D-xylose $\left(K_{\mathrm{i}} 19 \mathrm{~mm}\right)$ but not D-glucose. The size of the $T$. fusca enzyme is in the range reported for the few other bacterial $\beta$-xylosidases described, but the acidic nature of the protein and its affinity for the substrate have more in common with some of the monomeric $\beta$-xylosidases described in fungi.
\end{abstract}

\section{INTRODUCTION}

Xylan is the second most abundant renewable polysaccharide in nature and comprises a $\beta$-1,4linked D-xylose polymer with arabinofuranose, glucuronic acid and methylglucuronic acid side groups (Whistler \& Richards, 1970). In addition, arabinoxylan from hardwood species is often acetylated (Chesson et al., 1983; Timel, 1967). Consequently, complete hydrolysis requires the action of several different enzymes, possibly analogous to the synergistic enzyme action involved in crystalline cellulose degradation (Shewale, 1982). Endoxylanases randomly cleave the $\beta-1,4$ bonds in the polyxylose backbone to yield oligosaccharides of varying chain length. This activity has been described in a wide range of micro-organisms, including actinomycetes (Dekker \& Richards, 1976; McCarthy, 1987). More recently, the involvement of arabinofuranosidase, $\alpha$-glucuronidase, $\beta$-xylosidase and various esterases has been studied (Biely, 1985; MacKenzie et al., 1987; Puls et al., 1987) and various enzyme combinations have been shown to act synergistically (Biely et al., 1986; Deshpande et al., 1986). $\beta$-Xylosidase (EC 3.2.1.37; 1,4- $\beta$ $D$-xylan xylohydrolase) activity generates $D$-xylose from short-chain oligosaccharides and xylobiose and plays a crucial role in the relief of end-product inhibition of endoxylanase activity by xylobiose (Reilly, 1981).

In general, the xylan-degrading enzymes of fungi have received more attention than those of bacteria, and a number of fungal extracellular $\beta$-xylosidases have been characterized (John $e t$

Abbreviations: pNP, $p$-nitrophenol; pNPX, $p$-nitrophenyl $\beta$-D-xylopyranoside. 
al., 1979; Matsuo \& Yasui, 1984; Takenishi et al., 1973; Uziie et al., 1985). The first bacterial $\beta$ xylosidase isolated was from Bacillus pumilus (Kersters-Hilderson et al., 1969) and more recently the properties of a $\beta$-xylosidase from Clostridium acetobutylicum have been reported (Lee \& Forsberg, 1987). The $\beta$-xylosidase activity of a thermophilic Thermomonospora strain has been described as notable in that it exhibits broad $\mathrm{pH}$ and temperature optima (Ristroph \& Humphrey, 1985), although no attempt was made to isolate or purify the enzyme from crude cell extracts. In fact, Thermomonospora strains have attracted considerable attention as sources of highly active and thermostable enzymes for lignocellulose saccharification in general (McCarthy, 1987). Some progress has been made towards biochemical characterization of the cellulose-degrading system in Thermomonospora fusca (Calza et al., 1985) and we are adopting a similar approach to identification of the enzymes involved in xylan degradation. In this paper, purification and characterization of the thermostable intracellular $\beta$-xylosidase of $T$. fusca is described.

\section{METHODS}

Organism. Thirty strains of Thermomonospora fusca and $T$. curvata were screened for the production of extracellular xylanase and intracellular $\beta$-xylosidase activities when grown on xylan. $T$. fusca strain BD21 was selected as the most active producer of xylan-degrading enzymes under these conditions.

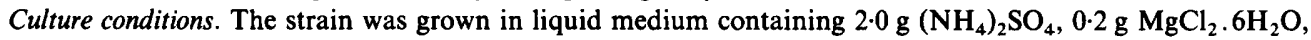
$11 \mathrm{mg} \mathrm{CaCl} 2,1.0 \mathrm{~g}$ yeast extract (Lab M), $2.0 \mathrm{~g}$ oat spelt xylan (Sigma) and $100 \mathrm{ml} 1.0 \mathrm{M}$-potassium phosphate buffer ( $\mathrm{pH} \mathrm{8.0)}$ in $900 \mathrm{ml}$ distilled water. Cultures were grown for $72 \mathrm{~h}$ at $50^{\circ} \mathrm{C}$ with shaking at 200 r.p.m. and harvested by centrifugation $(10 \mathrm{~min}$ at $10000 \mathrm{~g})$.

Enzyme assays. $\beta$-Xylosidase activity was measured by assaying the amount of $p$-nitrophenol (pNP) liberated from the substrate $p$-nitrophenyl $\beta$-D-xylopyranoside (pNPX, Sigma). The standard reaction mixture contained $650 \mu \mathrm{l} 10 \mathrm{mM}$-pNPX dissolved in $50 \mathrm{~mm}$-potassium phosphate buffer (pH 6.5) and $100 \mu \mathrm{l}$ (40-50 $\mu \mathrm{g}$ protein) of diluted intracellular enzyme preparation. After incubation at $55^{\circ} \mathrm{C}$ for $30 \mathrm{~min}$, the reaction was stopped by the addition of $1.5 \mathrm{ml} 1 \mathrm{M}-\mathrm{Na}_{2} \mathrm{CO}_{3}$ and the absorbance at $400 \mathrm{~nm}$ measured. This assay procedure was scaled down to a total volume of $200 \mu \mathrm{l}$, and addition of $\mathrm{Na}_{2} \mathrm{CO}_{3}$ omitted, for qualitative identification of active fractions in microtitre plates. One unit (U) of enzyme activity is defined as the amount of enzyme which produced $1 \mu \mathrm{mol} p N P$ $\mathrm{min}^{-1}$ under the above conditions, and specific activity is expressed in $\mathrm{U}$ (mg protein) ${ }^{-1}$. Arabinofuranosidase and $\beta$-glucosidase activities were measured by following the liberation of $\mathrm{pNP}$ from their respective pyranosides (Sigma) at $\mathrm{pH} 6.0$ and $50^{\circ} \mathrm{C}$.

Xylanase activity was determined by measuring the release of reducing sugar from oat spelt xylan as described by McCarthy et al. (1985). Endoglucanase activity was measured by replacing xylan with $20 \mathrm{mg}$ carboxymethylcellulose (low viscosity; BDH) in the xylanase assay.

Protein was measured by the Lowry method using bovine serum albumin (Sigma) as standard.

Purification of $\beta$-xylosidase. Harvested $T$. fusca cells were washed three times and resuspended in $5 \mathrm{ml} 100 \mathrm{mM}$ Tris/ $\mathrm{HCl}, \mathrm{pH} 7 \cdot 0$. Intracellular $\beta$-xylosidase activity was released by sonication for $10 \mathrm{~min}$ at $18 \mu \mathrm{m}$ peak-to-peak on ice. The crude lysate was cleared by centrifugation $(10 \mathrm{~min}$ at $10000 \mathrm{~g})$ and $0.03 \%(\mathrm{w} / \mathrm{v})$ sodium azide was added prior to storage at $-20^{\circ} \mathrm{C}$. Portions of this crude enzyme preparation were stored for up to 6 weeks, during which no significant loss in activity was detected.

The enzyme activity was concentrated and purified using fast protein liquid chromatography (FPLC). The first step involved anion-exchange chromatography using a Mono $Q$ HR $5 / 5$ column (Pharmacia) pre-equilibrated with $50 \mathrm{mM}$-Tris $/ \mathrm{HCl}, \mathrm{pH} 7.0$ (buffer A). Crude lysate $(1.5 \mathrm{ml} ; 2.5-3.0 \mathrm{mg}$ protein) was loaded onto the column and eluted with $1 \mathrm{M}-\mathrm{NaCl}$ in buffer $\mathrm{A}$ (buffer $\mathrm{B}$ ) at a flow rate of $1.0 \mathrm{ml} \mathrm{min}{ }^{-1}$ with the following gradient: $0 \% \mathrm{~B}$ in $4 \mathrm{ml} ; 0-35 \% \mathrm{~B}$ in $20 \mathrm{ml} ; 35-100 \% \mathrm{~B}$ in $4 \mathrm{ml}$. Fractions of the eluate were screened for $\beta$-xylosidase activity and the most active fractions pooled and immediately applied to a Superose 12 HR 10/30 column (Pharmacia) equilibrated with buffer $A$ and washed with $30 \mathrm{ml}$ buffer $A$ at a flow rate of $0.5 \mathrm{ml} \mathrm{min}^{-1}$. Protein was detected at $280 \mathrm{~nm}$ and fractions containing $\beta$-xylosidase activity were pooled and stored at $-20^{\circ} \mathrm{C}$.

Electrophoresis. Discontinuous SDS-PAGE and non-denaturing PAGE (Laemmli, 1970) were used to ascertain the degree of protein purity and confirm molecular masses derived from column chromatography data. Where appropriate, samples of protein were boiled for $5 \mathrm{~min}$ prior to electrophoresis on $10 \%(\mathrm{w} / \mathrm{v})$ polyacrylamide resolving gels at $40 \mathrm{~V}$ for $16 \mathrm{~h}$ using a vertical gel electrophoresis unit (BRL). After electrophoresis, protein bands were visualized by silver staining (Merril et al., 1981) using a commercially available kit (Bio-Rad). Molecular mass markers (SDS 6H and SDS 7; Sigma) were used in all gels. Polyacrylamide gels were also developed as zymograms to detect the presence of enzyme activity after electrophoresis. Prior to electrophoresis, samples were incubated at $50^{\circ} \mathrm{C}$ for $1 \mathrm{~h}$ in sample buffer, with or without SDS as appropriate. Immediately after electrophoresis, denaturing gels were soaked in $3 \times 400 \mathrm{ml}$ volumes of $40 \mathrm{mM}$-Tris/ $\mathrm{HCl}, \mathrm{pH} 6.5$ (non-denaturing 
gels were washed in only one volume of buffer), and sandwiched to a $1 \%(w / v)$ agarose gel containing $10 \mathrm{mM}$ pNPX, supported on gel bond (ICN Biomedicals). The gels were sealed in cling film and incubated at $50{ }^{\circ} \mathrm{C}$ for $1 \mathrm{~h}$. Enzyme activity was detected as a yellow band resulting from the release of pNP by $\beta$-xylosidase.

Chromatofocusing. The isoelectric point (pI) of the $\beta$-xylosidase was determined by focusing enzyme activity in the narrow $\mathrm{pH}$ range $4 \cdot 0-7 \cdot 0$. Samples of crude lysate $(500 \mu \mathrm{l} ; 0.8-1.0 \mathrm{mg}$ protein) were loaded onto a Mono P HR $5 / 20$ column (Pharmacia) pre-equilibrated with $25 \mathrm{~mm}$-Bis Tris, $\mathrm{pH} 7 \cdot 0$, and proteins were eluted with $40 \mathrm{ml}$ Polybuffer TM 65 (Pharmacia) $\mathrm{pH} 4.0$, at a flow rate of $0.5 \mathrm{ml} \mathrm{min}^{-1}$. Fractions $(1.0 \mathrm{ml})$ were collected and assayed for $\beta$-xylosidase activity. Isoelectric focusing was also performed using pre-cast polyacrylamide gels, $\mathrm{pH} \mathrm{3.5-9.5} \mathrm{(LKB).} \mathrm{They} \mathrm{were} \mathrm{developed} \mathrm{at} 880 \mathrm{~V}$ for $3 \mathrm{~h}$ using Shandon gel apparatus and broad-range pI markers (Pharmacia). These gels were developed as zymograms using the method described above.

$p H$ and temperature relationships. Portions of crude lysate or purified protein $(100 \mu l)$ were added to $650 \mu 1$ $10 \mathrm{mM}$-pNPX solution in Britton and Robinson Universal buffer (Johnson \& Lindsey, 1939) at pH values from 3.0 to 11.0 . These were then assayed for $\beta$-xylosidase activity as described above. Enzyme stability at $\mathrm{pH} 6.0$ and 8.0 was determined by incubating enzyme preparations at room temperature and assaying samples for $\beta$-xylosidase activity at intervals up to $72 \mathrm{~h}$.

The optimum temperature for assaying the $\beta$-xylosidase activity was determined by incubating assays in the range $30-80^{\circ} \mathrm{C}$ in a water bath for $30 \mathrm{~min}$. Thermostability was assessed by incubating enzyme preparations at 50 , 65 and $70^{\circ} \mathrm{C}$ and removing samples at hourly intervals. $\beta$-Xylosidase activity was determined after samples had been immediately cooled on ice.

The Michaelis-Menten kinetics of the crude and purified enzyme preparations were measured according to the method described by Ristroph \& Humphrey (1985). Samples containing $0.02 \mathrm{mg}^{2}$ protein $\mathrm{ml}^{-1}$ were used in all assays and the substrate concentration was varied from 0.045 to $10.0 \mathrm{mM}$-pNPX. Inhibition kinetics were determined by the addition of 20,50 and $90 \mathrm{mM}$-D-xylose or D-glucose to the reaction mixture.

\section{RESULTS AND DISCUSSION}

\section{Enzyme purification}

The $\beta$-xylosidase activity was concentrated and purified using two sequential steps: anion exchange and gel filtration chromatography. The final purification was approximately 14-fold and the mean overall yield was $95 \%$ (Table 1 ). In both separations, the $\beta$-xylosidase activity eluted as a single peak (Fig. 1), although the anion-exchange step resulted in only a partial purification (Fig. 2, lanes 3 and 4). The molecular mass of the enzyme was estimated at $168 \mathrm{kDa}$ $( \pm 10 \mathrm{kDa})$ using gel filtration chromatography with aldolase and glucose oxidase as molecular mass standards. The purified protein was detected as a single band on native PAGE (Fig. 2, lane 6), and the crude estimate of molecular mass obtained by this method was in agreement with the estimate obtained by gel filtration chromatography.

Denaturing PAGE further confirmed the homogeneity of the purified protein, giving a single band of approximately $56 \mathrm{kDa}( \pm 6 \mathrm{kDa})$, (Fig. 2, lane 5). This suggests that the native protein is composed of three subunits.

Native and SDS gels were also developed as zymograms. Native electrophoresis of the crude lysate (Fig. 2, lane 7) confirmed the presence of a single active intracellular $\beta$-xylosidase in $T$. fusca. This protein band was identical to the purified enzyme (Fig. 2, lane 8). Activity was only detected in native PAGE gels; no activity was found on SDS-PAGE gels developed as zymograms, indicating that the subunits were inactive.

The estimated molecular mass of the $T$. fusca $\beta$-xylosidase $(168 \mathrm{kDa})$ is well within the range reported for other bacterial $\beta$-xylosidases (Claeyssens et al., 1975; Lee \& Forsberg, 1987; Panbangred et al., 1984). Furthermore, the $\beta$-xylosidase of Clostridium acetobutylicum is also described as having a trimeric structure, although heterogeneous, comprising one $63 \mathrm{kDa}$ and two $85 \mathrm{kDa}$ subunits (Lee \& Forsberg, 1987). In contrast, the $\beta$-xylosidases of fungi described to date are monomeric proteins of lower molecular masses, in the range 83-102 kDa (Deleyn et al., 1978; Deshpande et al., 1986; Matsuo \& Yasui, 1984).

\section{Isoelectric point}

The $\mathrm{pI}$ of the $\beta$-xylosidase was estimated by chromatofocusing as 4.37 , indicating that the enzyme is an acidic protein. This was to some extent confirmed by the presence of a single band of activity at $\mathrm{pH} 4.5$ (data not shown) on an isoelectric focusing gel (developed as a zymogram) 

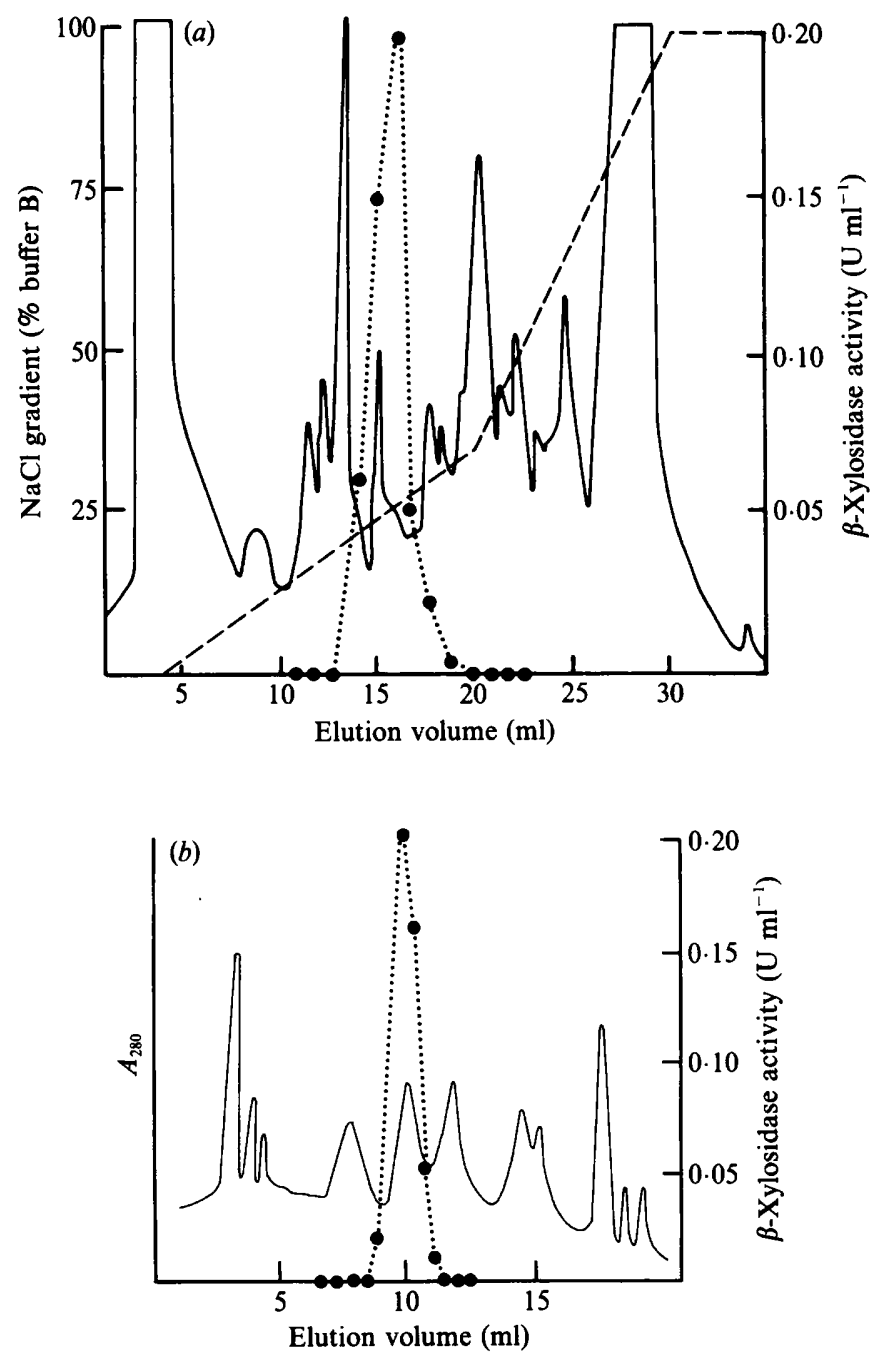

Fig. 1. Purification of $T$. fusca $\beta$-xylosidase by FPLC. (a) Elution profile after anion-exchange chromatography on Mono Q HR5/5. (b) Elution profile after the pooled $\beta$-xylosidase activity from the Mono Q column was separated by gel filtration on Superose 12 . - , $A_{280} ;---, \mathrm{NaCl}$ gradient (see Methods for actual concentrations); $\cdots \cdot, \beta$-xylosidase activity.

Table 1. Purification of intracellular $\beta$-xylosidase

\begin{tabular}{lcccc}
\multicolumn{1}{c}{ Step } & $\begin{array}{c}\text { Total } \\
\text { protein } \\
(\mathrm{mg})\end{array}$ & $\begin{array}{c}\text { Total } \\
\text { activity } \\
(\mathrm{U})\end{array}$ & $\begin{array}{c}\text { Specific } \\
\text { activity } \\
\text { [U (mg protein) }\end{array}$ & $\begin{array}{c}\text { Yield } \\
(\%)\end{array}$ \\
Cleared lysate & 3.03 & 1.69 & 0.56 & 100 \\
Mono Q eluate & 0.41 & 1.15 & 2.81 & $68^{*}$ \\
Superose 12 eluate & $\mathbf{0 . 2 0}$ & 1.60 & 8.00 & 95
\end{tabular}

* This apparent reduction in yield is probably due to the inhibitory effect of $\mathrm{NaCl}$ on enzyme activity. We have shown that $T$. fusca $\beta$-xylosidase activity is sensitive to $\mathrm{NaCl}$ and expected an approximately $25 \%$ loss in yield (data not shown). 


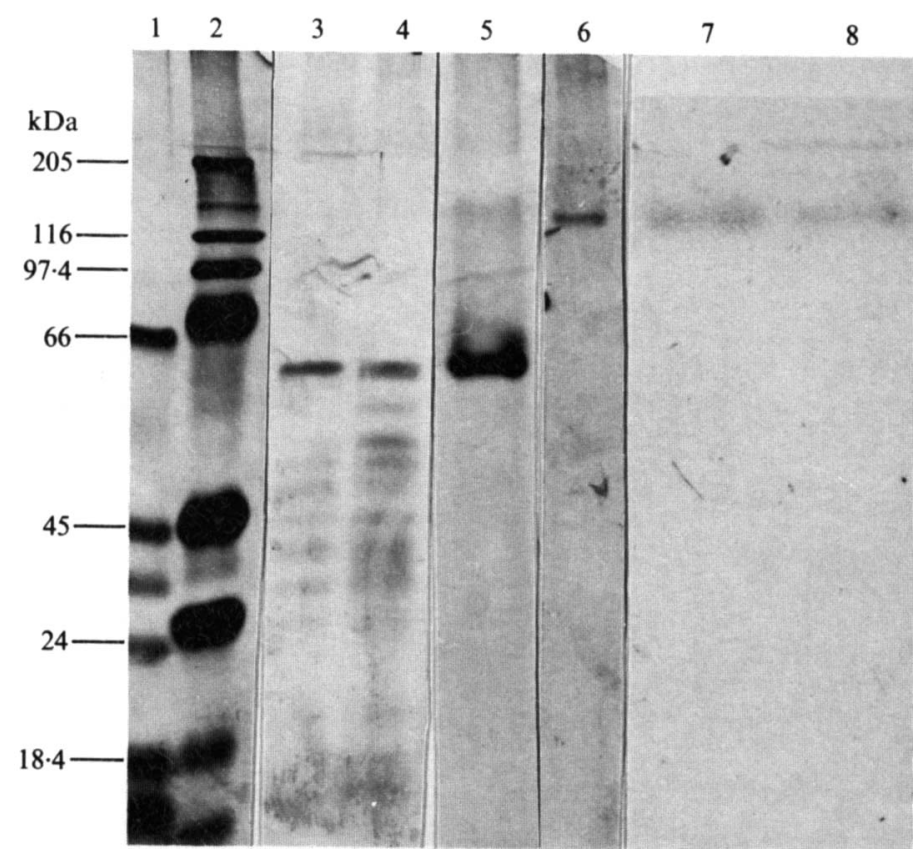

Fig. 2. PAGE of $T$. fusca $\beta$-xylosidase purified by FPLC. Active fractions were analysed by SDSPAGE and proteins were detected by silver staining: lanes 3 and 4 , partially purified protein after anion-exchange chromatography; lane 5 , protein after further purification by gel filtration chromatography. The purified enzyme was also visualized by native PAGE and silver staining (lane 6). Lanes 7 and 8, native PAGE of the crude lysate (lane 7) and purified protein (lane 8) with gels developed as zymograms by overlaying with pNPX. Lanes 1 and 2, molecular mass markers. Lanes 3, 4 and 6 were loaded with $25 \mu \mathrm{g}$ protein, lane 5 with $50 \mu \mathrm{g}$ protein and lane 7 with $75 \mu \mathrm{g}$ protein.

loaded with crude enzyme preparation and standards of known pI (Pharmacia). The $\beta$ xylosidase of $T$. fusca is therefore more acidic than the other bacterial $\beta$-xylosidases described (Kersters-Hilderson et al., 1969; Lee \& Forsberg, 1987), but is similar in pI to those produced by fungi (Deshpande et al., 1986; Matsuo \& Yasui, 1984; Takenishi et al., 1973).

\section{pH and temperature relationships}

Under the assay conditions described, the effect of $\mathrm{pH}$ and temperature were identical for the crude and purified enzyme preparations. In the range $\mathrm{pH} 5 \cdot 0-9 \cdot 0, \beta$-xylosidase exhibited 90 $100 \%$ of its maximum activity, with approximately $30 \%$ detected outside this range. In a separate experiment, the $\beta$-xylosidase activity was found to be stable at room temperature at

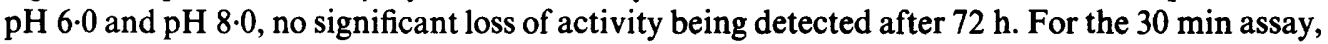
maximum yields of product ( $\mathrm{pNP}$ ) were recorded with incubation at $40-60^{\circ} \mathrm{C}$. As the assay temperature was increased above $60^{\circ} \mathrm{C}$, enzyme activity decreased: at $70{ }^{\circ} \mathrm{C}$ activity was approximately $50 \%$ of the maximum. These effects of assay temperature are reflected in the thermostability data for the purified $\beta$-xylosidase (Fig. 3). The enzyme lost no activity when incubated at $50{ }^{\circ} \mathrm{C}$ for $8 \mathrm{~h}$ prior to assay, but exhibited a half-life of $8 \mathrm{~h}$ at $65^{\circ} \mathrm{C}$ and $1.5 \mathrm{~h}$ at $70^{\circ} \mathrm{C}$. The $T$. fusca $\beta$-xylosidase appears therefore to be more thermostable than the $\beta$ xylosidases of fungi and other bacteria studied to date, and exhibits activity across a relatively broad $\mathrm{pH}$ range.

\section{Kinetics of $\beta$-xylosidase activity}

The affinity of the $T$. fusca $\beta$-xylosidase for the substrate pNPX was examined using a Lineweaver-Burk plot. The apparent $K_{\mathrm{m}}$ for the crude preparation was $0.97 \mathrm{~mm}$ (standard deviation $0.01 ; n=3$ ) and for the purified enzyme, $0.89 \mathrm{mM}$ (standard deviation $0.01 ; n=3$ ). 


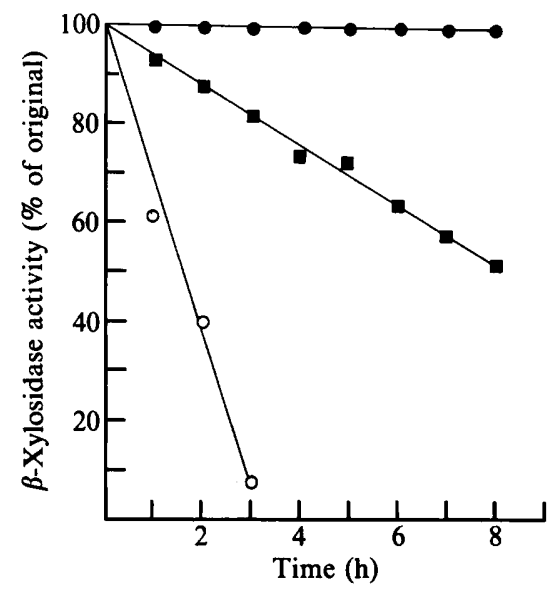

Fig. 3. Thermostability profiles of purified $T$. fusca $\beta$-xylosidase. Purifed enzyme was held at $50^{\circ} \mathrm{C}$ $(\bigcirc), 65^{\circ} \mathrm{C}(\square)$ and $70^{\circ} \mathrm{C}(\mathrm{O})$. All the results are the means of three replicates; standard deviations were within $\pm 5 \%$ of the mean.

These values are in accord with the apparent $K_{\mathrm{m}}$ published for the crude $\beta$-xylosidase activity of a different Thermomonospora strain (Ristroph \& Humphrey, 1985). The Neurospora crassa and Aspergillus $\beta$-xylosidases show a greater affinity for this substrate than the $T$. fusca enzyme, with apparent $K_{\mathrm{m}}$ values of $0.05 \mathrm{~mm}$ and $0.22 \mathrm{~mm}$ respectively (Deshpande et al., 1986; John et al., 1979). However, other bacterial and fungal enzymes studied show less affinity for this substrate than the $T$. fusca enzyme.

The enzyme was not inhibited by D-glucose but it was inhibited by D-xylose, with an inhibition constant of $19 \cdot 1 \mathrm{mM}$ (standard deviation $1 \cdot 3 ; n=3$ ) xylose. End-product inhibition of $\beta$-xylosidase activity by xylose is important in limiting the rate of lignocellulose saccharification in any process, since it is likely that the action of $\beta$-xylosidase itself, in removing oligosaccharides inhibitory to endoxylanase activity, would be a key regulatory mechanism.

\section{Substrate specificity}

The purified $\beta$-xylosidase did not exhibit detectable endoxylanase, endoglucanase or $\beta$ glucosidase activities. However, very low levels of arabinofuranosidase activity were detected after prolonged (overnight) incubation of the reaction mixture. This is likely to be due to the presence of small amounts of contaminating $\alpha$-arabinofuranosidase activity, since this activity elutes from the anion-exchange column immediately before the $\beta$-xylosidase activity (data not shown). Furthermore, the separation between arabinofuranosidase and $\beta$-xylosidase by gel filtration is incomplete, probably resulting in the presence of trace amounts of arabinofuranosidase undetectable by PAGE. However, relatively broad substrate specificities are not uncommon amongst enzymes involved in the hydrolysis of cellulosic substrates, and fungal $\beta$ xylosidases with additional arabinofuranosidase activity (Deleyn et al., 1978) or $\beta$-glucosidase activity (Uziie et al., 1985) have been reported. No comparable information is available for the few bacterial $\beta$-xylosidases described thus far.

In addition to the high levels of intracellular $\beta$-xylosidase activity in $T$. fusca, low levels can be detected in the culture supernatant. Preliminary analysis indicates that this activity is due to a protein which is chromatographically identical to the intracellular $\beta$-xylosidase, suggesting leakage of the intracellular protein into the surrounding medium. As in other bacteria, therefore, $T$. fusca $\beta$-xylosidase is an intracellular enzyme and apparent detection of extracellular activity should be interpreted with caution.

Although few bacterial $\beta$-xylosidases have been characterized, that produced by $T$. fusca appears to be similar in size to these enzymes, and distinct from the smaller, monomeric $\beta$ xylosidases described in fungi. The broad $\mathrm{pH}$ and temperature stabilities of the $T$. fusca enzyme 
compare favourably with those from other micro-organisms in general, further supporting the potential of thermophilic actinomycetes as a source of enzymes for lignocellulose saccharification.

This work was partly supported by the EEC Non-Nuclear Energy Programme. Susan L. Bachmann was supported by a studentship from the Science and Engineering Research Council. We are grateful to Professor G. A. O'Donovan, University of North Texas, for critical review of the manuscript.

\section{REFERENCES}

BIELY, P. (1985). Microbial xylanolytic systems. Trends in Biotechnology 3, 286-290.

Biely, P., MacKenzie, C. R., Puls, J. \& Schneider, H. (1986). Cooperativity of esterases and xylanases in the enzymatic degradation of acetyl xylan. Biotechnology 4, 731-733.

Calza, R. E., IRWin, D. C. \& Wilson, D. B. (1985). Purification and characterisation of two $\beta-1,4-$ endoglucanases from Thermomonospora fusca. Biochemistry 24, 7797-7804.

Chesson, A., Gordon, A. H. \& Lomax, J. A. (1983). Substituent groups linked by alkali labile bonds to arabinose and xylose residues of legume, grass and cereal straw walls and their fate during digestion by rumen microorganisms. Journal of the Science of Food and Agriculture 34, 1330-1340.

Claeyssens, M., Saman, E., Kersters-Hilderson, H. \& DE BRUYNE, C. K. (1975). $\beta$-D-Xylosidase from Bacillus pumilus: molecular properties and oligomeric structure. Biochimica et biophysica acta 405, 475-481.

DEKKER, R. F. H. \& RiChARDS, G. N. (1976). Hemicellulases: their occurrence, properties and mode of action. In Advances in Carbohydrate Chemistry and Biochemistry, pp. 278-352. Edited by R. S. Tipson \& D. Horton. London: Academic Press.

Deleyn, F., Claeyssens, M., van Beelmen, J. \& De BRUYNE, C. K. (1978). Purification and properties of $\beta$-xylosidase from Penicillium wortmanni. Canadian Journal of Biochemistry 56, 43-50.

Deshpande, V., LachKe, A., Mishra, C., Keskar, S. \& RAO, M. (1986). Mode of action and properties of xylanase and $\beta$-xylosidase from Neurospora crassa. Biotechnology and Bioengineering 28, 1832-1837.

JoHN, M., SchmidT, B. \& SCHMIDT, J. (1979). Purification and some properties of five endo-1,4, $\beta$-Dxylanases and a $\beta$-D-xylosidase produced a strain of Aspergillus niger. Canadian Journal of Biochemistry 57, $125-134$.

Johnson, W. C. \& Lindsey, A. J. (1939). An improved universal buffer. Analyst 64, 490-492.

Kersters-Hilderson, H., LoONtiens, F. G., ClaeysSENS, M. \& BRUYNE, C. K. (1969). Partial purification and properties of an induced $\beta$-D-xylosidase of Bacillus pumilus 12. European Journal of Biochemistry 7, 434-441.

LAEMMLI, U. K. (1970). Cleavage of structural proteins during the assembly of the head of bacteriophage T4. Nature, London 227, 680-685.

LEE, S. F. \& ForSBERG, C. W. (1987). Isolation and some properties of a $\beta$-D-xylosidase from Clostridium acetobutylicum A TCC824. Applied and Environmental Microbiology 53, 651-654.
MCCARTHY, A. J. (1987). Lignocellulose-degrading actinomycetes. FEMS Microbiology Reviews 46, 145163.

McCarthy, A. J., Peace, E. \& Broda, P. (1985). Studies on the extracellular xylanase activities of some thermophilic actinomycetes. Applied Microbiology and Biotechnology 21, 238-244.

MacKenzie, C. R., Bilous, D., Schneider, H. \& JoHNSON, K. G. (1987). Induction of cellulolytic and xylanolytic enzyme systems in Streptomyces sp. Applied and Environmental Microbiology 53, 28352839.

Matsuo, M. \& Yasui, T. (1984). Purification and properties of $\beta$-D-xylosidase from Trichoderma viride. Agricultural and Biological Chemistry 48, 1845-1852.

Merril, C. R., Goldman, D., Sedman, S. A. \& Ebert, M. H. (1981). Ultrasensitive stain for proteins in polyacrylamide gels shows regional variation in cerebrospinal fluid proteins. Science 211, 1437-1438.

Panbangred, W., Kawaguchi, O., Tomita, T., ShINmyo, A. \& OKaDA, H. (1984). Isolation of two $\beta$ xylosidase genes of Bacillus pumilus and comparison of their gene products. European Journal of Biochemistry 138, 267-273.

Puls, J., SchmidT, O. \& Granzow, C. (1987). Glucuronidase in two microbial xylanolytic systems. Enzyme and Microbial Technology 9, 83-88.

ReILlY, P. J. (1981). Xylanases: structure and function. In Trends in the Biology of Fermentation for Fuels and Chemicals, pp. 111-129. Edited by A. E. Hollaender. New York: Plenum.

RISTROPH, D. L. \& HUMPHREY, A. E. (1985). The $\beta$ xylosidase of Thermomonospora. Biotechnology and Bioengineering 27, 909-913.

ShewALE, J. G. (1982). $\beta$-Glucosidase: its role in cellulase synthesis and hydrolysis of cellulose. International Journal of Biochemistry 14, 435-443.

Takenishi, S., Tsuliska, Y. \& Fukomoto, J. (1973). Studies on hemicellulases. IV. Purification and properties of the $\beta$-xylosidase produced by Aspergillus niger van Tieghem. Journal of Biochemistry 73, 335-343.

TIMEL, T. E. (1967). Recent progress in the chemistry of wood hemicellulose. Wood Science and Technology 1, 45-70.

Uzire, M., Matsuo, M. \& Yasui, T. (1985). Possible identity of $\beta$-xylosidase and $\beta$-glucosidase of Chaetomium trilaterale. Agricultural and Biological Chemistry 49, 1167-1173.

Whistler, R. H. A. \& Richards, E. L. (1970). Hemicellulose. In The Carbohydrates, pp. 447-469. Edited by W. Pigman \& D. Horton. New York: Academic Press. 